\title{
An unusual obstacle to the thoracic interlaminar epidural injection for the treatment of post-herpetic neuralgia
}

\author{
Postherpetik nevralji tedavisinde torasik interlaminar epidural enjeksiyonuna \\ beklenmedik bir engel
}

\author{
(1) Serhad BíLiM, (1) Savaş ŞENCAN, (1) Osman Hakan GÜNDÜZ
}

\begin{abstract}
Summary
Interlaminar epidural steroid injections corresponding to dermatomes affected by post-herpetic neuralgia (PHN) were found effective in reducing pain. Diffuse idiopathic skeletal hyperostosis (DISH) is a non-inflammatory condition that mainly occurs with calcification and ossification of spinal ligaments such as anterior and posterior longitudinal, interspinous, supraspinous ligament, and ligamentum flavum. In this case, it is presented that the failure of the access to the T7-T8 interlaminar space due to the supra/interspinous ligament calcification and ossification accompanied by thoracic DISH in a 73-year-old male for the treatment of PHN.
\end{abstract}

Keywords: Diffuse idiopathic skeletal hyperostosis; epidural injection; pathologic calcification; postherpetic neuralgia; thoracic spondylosis; thoracic vertebrae.

\begin{abstract}
Özet erişimin başarısız olma durumu sunuldu. torakal vertebra.
\end{abstract}

Postherpetik nevraljide etkilenen dermatomlara yönelik interlaminar epidural steroid enjeksiyonlarının ağrıyı azaltmada etkili olduğu bulundu. Diffüz idiyopatik iskelet hiperostozu esas olarak anterior ve posterior longitudinal ligament, interspinöz, supraspinöz ligament ve ligamentum flavum gibi spinal ligamentlerin kalsifikasyonu ve kemikleşmesi ile ortaya çıkan inflamatuvar olmayan bir durumdur. Bu olguda, 73 yaşında postherpetik nevraljisi olan bir erkek hastada, torakal diffüz idiyopatik iskelet hiperostoza eşlik eden supra/interspinöz ligament kalsifikasyonu ve kemikleşme nedeniyle T7-T8 interlaminar epidural alana

Anahtar sözcükler: Epidural Enjeksiyon; diffüz idiopatik iskelet hiperostozu; patolojik kalsifikasyon; postherpetik nevralji; torakal spondiloz;

\section{Introduction}

Post-herpetic neuralgia (PHN) which refers to pain lasting more than 4 months beyond healing of the rash is the most common complication of acute herpes zoster. The pain has been described as a constant or intermittent, burning, or stabbing sensation and most of patients with PHN also have allodynia. ${ }^{[1]}$ Epidural steroid injections are used for the treatment of pain associated with herpes zoster. ${ }^{[2]}$ Interlaminar epidural steroid injections corresponding to dermatomes affected by the disease were found effective in reducing pain. ${ }^{[3]}$
Diffuse idiopathic skeletal hyperostosis (DISH) is a non-inflammatory condition that mainly occurs with calcification and ossification of spinal ligaments and entheses. The presence of continuous ossification along the anterolateral aspect of at least four contiguous vertebral bodies especially in the thoracolumbar spine is used as diagnostic criteria. ${ }^{[4]}$ Although calcification and ossification of ligaments occurs in anterolateral site of vertebral bodies in patients with DISH. ${ }^{[5]}$ It may occur in posterior paraspinal ligaments such as supra/interspinous ligaments. ${ }^{[6]}$ The calcification and ossification of these ligaments at the in- 
terlaminar epidural injection level may prevent the needle from reaching the epidural area. Therefore, the effectiveness of interlaminar epidural injections that cannot be made at the affected level may also be low. In this case, the failure of the access to the T7T8 interlaminar space due to the supra/interspinous ligament calcification and ossification accompanied by thoracic DISH in a 73-year-old male for the treatment of $\mathrm{PHN}$ is presented.

\section{Case Report}

A 73-year-old man was referred to our pain clinic for advanced pain management due to failure of medical treatment. The patient reported a severe burn sensation and constant pain started in the right back 4 months ago. He took non-steroid anti-inflammatory drugs. After 1 day, he noticed the eruption of vesicles over the right back and applied to hospital. He was diagnosed with acute herpes zoster and hospitalized. Discolored scarring over his right back and chest wall corresponding to the dermatome of T6-T8 was seen. Gabapentin 600 mg twice a day, duloxetine $30 \mathrm{mg}$ once a day, and acetaminophen 500 $\mathrm{mg} /$ codeine phosphate $30 \mathrm{mg} 3$ times a day were prescribed. After 1 month, he reported that his pain was not effectively decreased. The numeric rating scale (NRS) score for pain was ten out of ten. Therefore, the thoracic interlaminar epidural steroid injection in the T7-T8 interlaminar space was planned.

The patient was placed in the prone position and the thoracic area was anesthetized in sterile fashion. The fluoroscope was then tilted caudad to maximize the T7-T8 interlaminar space between the overlapping laminae and spinous processes. A 20-gauge, 10-cm Tuohy needle, was advanced under fluoroscopic guidance with a right paramedian approach. However, the needle could not be advanced through supra/interspineous ligaments (Fig. 1). After a few tries, the Tuohy needle was directed to the T12-L1 interlaminar space which was seen more obviously. Then, an epidural catheter was inserted with the tip advanced to T7 level. After contrast, media was seen in the epidural space, $80 \mathrm{mg}$ triamcinolone and $10 \mathrm{mg}$ 0.5\% bupicavaine were given. The procedure was completed without major complications. After $1 \mathrm{~h}$ of the procedure, he had no complaints except a minimal pain at the injection site and was discharged.

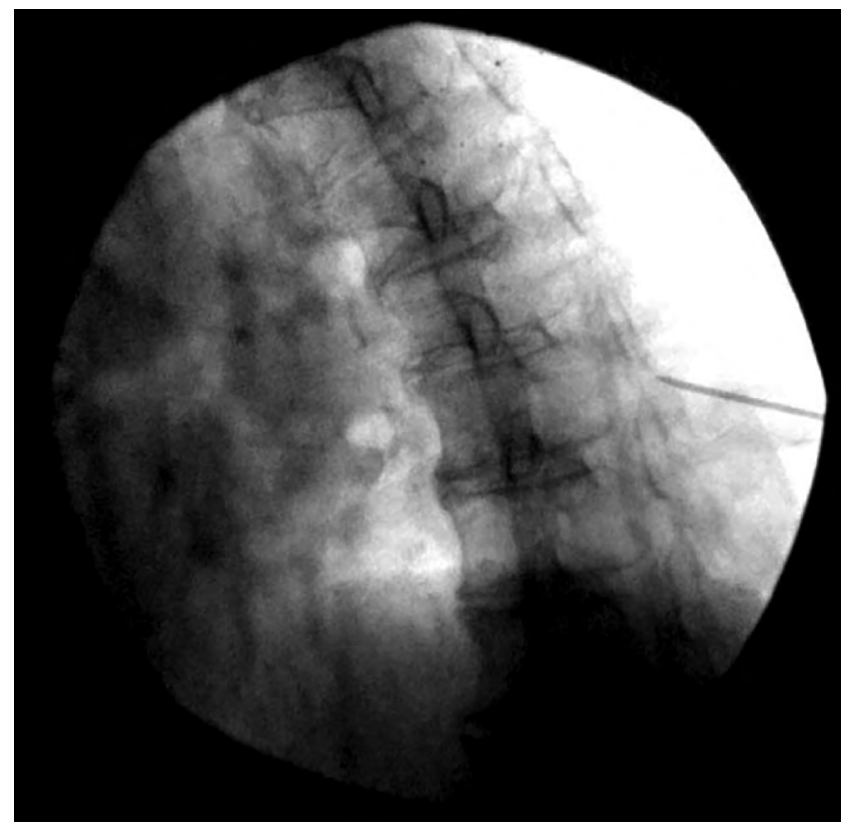

Figure 1.Lateral radiograph of the thoracic spine during interlaminar thoracic epidural injection. A Tuohy needle not advanced through the T7-T8 interlaminar space.

After procedure, thoracic spine X-ray and computed tomography of the patient were examined (Fig. 2). The presences of continuous ossification along the anterolateral aspect of T6-T10 that compatible with the DISH was noticed. The calcification and ossification of supra/interspinous ligaments corresponding to these levels were also seen. This explained the failure of interlaminar injection at this level. After 1 h of procedure, NRS for pain was 6 out of 10. After 4 weeks, his pain was almost the same as it was before procedure (NRS 9 out of 10).

\section{Discussion}

In this case, the failure of the access to the T7-T8 interlaminar space due to the supra/interspinous ligament calcification and ossification accompanied by thoracic DISH in a 73-year-old male for the treatment of PHN is presented. After a few tries, the needle was directed to the T12-L1 interlaminar space and epidural catheter was inserted with the tip advanced to T7. The procedure was completed without major complications. After 1 month, his pain was similar to the pain before the procedure.

DISH is characterized by the calcification and ossification of ligaments and entheses. The calcification and ossification of anterior longitudinal ligament, especially right-sided is the most prominent finding of DISH. ${ }^{[5]}$ Besides, calcification and ossification 


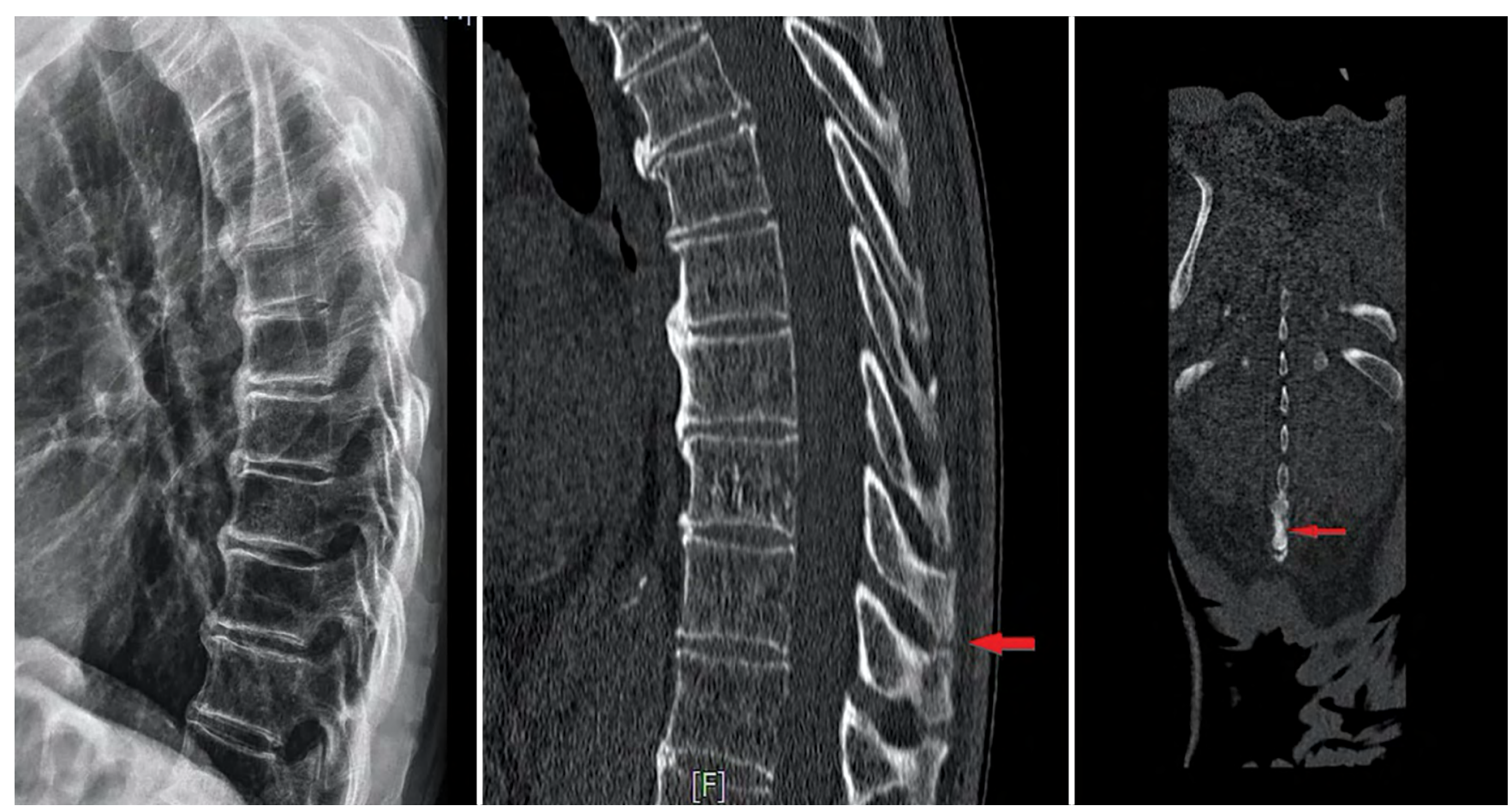

Figure 2. Thoracic X-ray and computed tomography $(\mathrm{CT})$ of the patient. X-ray shows the presences of continuous ossification along the anterolateral aspect of thoracic spine. CT shows the calcification and ossification of supra/interspinous ligaments (red arrows).

may occur in other paravertebral ligaments such as posterior longitudinal, interspinous, supraspinous ligament, and ligamentum flavum. ${ }^{[6]}$ The prevalence of supra/interspinous ligament ossification in patients with cervical radiculopathy due to posterior ligament ossification was found $29 \% \cdot{ }^{[7]}$ In our case, supra/interspinous calcification and ossification, which is less frequently observed in DISH, was detected. It is known that interspinous ligament calcification and ossification may be a potential anatomic impediment to the interlaminar epidural steroid injection. ${ }^{[8]}$ Therefore, in the patients with DISH, radiological examination of supra/interspinous ligament calcification and ossification may be important for the prevention of possible unsuccessful interlaminar epidural steroid injections.

Herpes zoster (shingles) is a condition that occurs after the reactivation of the Varisella Zoster virus that becomes latent in the dorsal root ganglia after the first infection or vaccination. ${ }^{[9]} \mathrm{PHN}$ is the most common complication of acute herpes zoster. ${ }^{[1]}$ Older age, greater acute pain and rash severity, $^{[10]}$ and immune suppression ${ }^{[11]}$ are risk factors for acute herpes neuralgia becoming to the PHN. In our case, severe rash and severe acute pain of his acute herpes and patient's older age may be associated with PHN.
Gabapentin, ${ }^{[12]}$ pregabalin, ${ }^{[13]}$ tricyclic antidepressants such as amitriptyline, ${ }^{[14]}$ and opioids ${ }^{[15]}$ are effective for the treatment of $\mathrm{PNH}$. These medications are prescribed with the recommended starting dose and increased until adequate clinical response is obtained. However, they have significant intolerable side effects limiting the dose. In cases which oral therapy is not effective, botulinium toxin injections over the affected area, ${ }^{[16]}$ sympathetic ganglion blocks, ${ }^{[17]}$ and the affected nerve blocks ${ }^{[18]}$ may be used. Although epidural injections have been used both to treat zoster-associated pain and to prevent $\mathrm{PHN}^{\left[{ }^{[19]}\right.}$ they can also use to relieve symptoms of patients with PHN. ${ }^{[20]}$

However, in our case, the interlaminar epidural steroid injection with the epidural catheter that the tip was advanced to T7 level was not effective. This situation may be related to the inability of injection directly to the affected level due to the calcification and ossification of supra/inter ligaments and the whole injectate may not have been given to this level. In addition, the effectiveness of epidural injections has been demonstrated in the acute period of herpes-related pain, but, in our case, the patient was in the chronic period of pain.

This case is valuable in that it demonstrates that supra/interspinous ligaments calcification and ossifica- 
tion, which can occur in patients with DISH, may be one of the technical and therapeutic failure in the thoracic epidural injection.

The epidural steroids injections are used to relieve symptoms of patients with PHN. If these patients also have DISH which can be seen calcification and ossification of paravertebral ligaments, it may be more appropriate to plan the transforaminal route instead of the interlaminar route.

\section{Informed Consent: Written informed consent was ob- tained from the patient for the publication of the case report and the accompanying images.}

Conflict-of-interest issues regarding the authorship or article: None declared.

Peer-rewiew: Externally peer-reviewed.

\section{References}

1. Johnson RW, Rice ASC. Clinical practice. Postherpetic neuralgia. N Engl J Med 2014;371:1526-33. [CrossRef]

2. van Wijck AJ, Opstelten W, Moons KG, van Essen GA, Stolker RJ, Kalkman CJ, et al. The PINE study of epidural steroids and local anaesthetics to prevent postherpetic neuralgia: A randomised controlled trial. Lancet 2006;367:219-24.

3. Fujiwara A, Watanabe K, Hashizume K, Shinohara K, Kawaguchi M. Transforaminal vs interlaminar epidural steroid injection for acute-phase shingles: A randomized, prospective trial. Pain Physician 2018;21:373-82. [CrossRef]

4. Utsinger PD. Diffuse idiopathic skeletal hyperostosis. Clin Rheum Dis 1985;11:325-51. [CrossRef]

5. Mader R, Sarzi-Puttini P, Atzeni F, Olivieri I, Pappone N, Verlaan JJ, et al. Extraspinal manifestations of diffuse idiopathic skeletal hyperostosis. Rheumatology (Oxford) 2009;48:1478-81.

6. Olivieri I, D’Angelo S, Palazzi C, Padula A, Mader R, Khan MA. Diffuse idiopathic skeletal hyperostosis: Differentiation from ankylosing spondylitis. Curr Rheumatol Rep 2009;11:321-8. [CrossRef]

7. Mori K, Yoshii T, Hirai T, Iwanami A, Takeuchi K, Yamada T, et al. Prevalence and distribution of ossification of the supra/interspinous ligaments in symptomatic patients with cervical ossification of the posterior longitudinal ligament of the spine: A CT-based multicenter cross-sectional study.
BMC Musculoskelet Disord 2016;17:492. [CrossRef]

8. Hameed F, Hunter DJ, Rainville J, Li L, Suri P. Prevalence of anatomic impediments to interlaminar lumbar epidural steroid injection. Arch Phys Med Rehabil 2012;93:339-43.

9. Sampathkumar P, Drage LA, Martin DP. Herpes zoster (shingles) and postherpetic neuralgia. Mayo Clin Proc 2009;84:274-80. [CrossRef]

10. Forbes HJ, Bhaskaran K, Thomas SL, Smeeth L, Clayton T, Mansfield K, et al. Quantification of risk factors for postherpetic neuralgia in herpes zoster patients: A cohort study. Neurology 2016;87:94-102. [CrossRef]

11. Rice ASC, Maton S; Postherpetic Neuralgia Study Group. Gabapentin in postherpetic neuralgia: A randomised, double blind, placebo controlled study. Pain 2001;942:215-24. [CrossRef]

12. Singh D, Kennedy DH. The use of gabapentin for the treatment of postherpetic neuralgia. Clin Ther 2003;25:852-89.

13. Dworkin $\mathrm{RH}$, Corbin AE, Young JP Jr, Sharma U, LaMoreaux $\mathrm{L}$, Bockbrader $\mathrm{H}$, et al. Pregabalin for the treatment of postherpetic neuralgia: A randomized, placebo-controlled trial. Neurology 2003;60:1274-83. [CrossRef]

14. Moore RA, Derry S, Aldington D, Cole P, Wiffen PJ. Amitriptyline for neuropathic pain and fibromyalgia in adults. Cochrane Database Syst Rev 2012;12:CD008242. [CrossRef]

15. Hempenstall K, Nurmikko TJ, Johnson RW, A'Hern RP, Rice AS. Analgesic therapy in postherpetic neuralgia: A quantitative systematic review. PLoS Med 2005;2:e164. [CrossRef]

16. Xiao L, Mackey S, Hui H, Xong D, Zhang Q, Zhang D. Subcutaneous injection of botulinum toxin a is beneficial in postherpetic neuralgia. Pain Med 2010;11:1827-33.

17. Wu CL, Marsh A, Dworkin RH. The role of sympathetic nerve blocks in herpes zoster and postherpetic neuralgia. Pain 2000;87:121-9. [CrossRef]

18. Kumar V, Krone K, Mathieu A. Neuraxial and sympathetic blocks in herpes zoster and postherpetic neuralgia: An appraisal of current evidence. Reg Anesth Pain Med 2004;29:454-61. [CrossRef]

19. Xing XF, Zhou ZF, Zhang FJ, Yan M. The effect of early use of supplemental therapy on preventing postherpetic neuralgia: A systematic review and meta-analysis. Pain Physician 2017;20:471-86. [CrossRef]

20. Ghanavatian S, Wie CS, Low RS, Butterfield RJ, Zhang N, Dhaliwal GS, et al. Parameters associated with efficacy of epidural steroid injections in the management of postherpetic neuralgia: The Mayo Clinic experience. J Pain Res 2019;12:1279-86. [CrossRef] 